\title{
Table of statutes
}

\section{International}

Agreement on Trade-Related Aspects of Intellectual Property Rights, 1994 76, 88-90, 109, 112-14, 214, 215, 218

Paris Convention for the Protection of Industrial Property, 1883 89, 108, 113, 114

\section{Europe}

Commission Decision No. 2002/165/ $E C$, L 59 Official Journal 18 (2002) 67, 68
Commission Notice on the Definition of the Relevant Market for the Purpose of Community Competition Law, C372 Official Journal 5 (1997) $\mathbf{5 6 , 5 7}$ EU, Council Directive 91/250/EEC of 14 May 1991 on the legal protection of computer programs, Official Journal L122 (1991): 42 6 